\title{
VARIABILITY IN THE COMPLEXITY OF PATIENT'S NURSING CARE NEEDS
}

\author{
Vivian Brito de Araújo $^{1}$ \\ Márcia Galan Perroca ${ }^{2}$ \\ Marli de Carvalho Jericó ${ }^{3}$
}

Araújo VB, Perroca MG, Jericó MC. Variability in the complexity of patient's nursing care needs. Rev Latino-am Enfermagem 2009 janeiro-fevereiro; 17(1):34-39.

The aim of this descriptive-exploratory study was to investigate the variability in the complexity of patients' nursing care needs during hospitalization and to identify the care indicators that most contribute to the transition between categories. The study was carried out at clinical and surgical inpatient units of a teaching hospital in the interior of São Paulo State. We included 80 patients from hospital admission to patient discharge, applying a classification instrument proposed and validated by Perroca. In both clinical and surgical inpatient units, patients who were classified into the minimal care category were predominant, $73 \%$ and $46 \%$, respectively. Most of the clinical patients remained in the care category identified upon admission, while the surgical patients varied among the care categories, mainly in the post-operative period. Personal hygiene, locomotion and skin integrity were the most involved care indicators in the transition between care categories. The findings can support management decisions.

DESCRIPTORS: nursing assessment; workload; inpatients/classification

\section{VARIABILIDAD DEL GRADO DE COMPLEJIDAD ASISTENCIAL DEL PACIENTE CON RELACIÓN AL EQUIPO DE ENFERMERÍA}

Este estudio de carácter investigativo-descriptivo tuvo como finalidad investigar la variabilidad de la complejidad asistencial del paciente respecto al equipo de enfermería durante la internación e identificar los indicadores de cuidados que contribuyen más para la transición entre las categorías. Se llevó a cabo en unidades de clínica médica y quirúrgica de un hospital escuela del interior del Estado de San Pablo. Fueron clasificados 80 pacientes desde la admisión hasta la alta médica, utilizando el instrumento de clasificación propuesto y aprobado por Perroca. Tanto en las unidades de internación médica como en las quirúrgicas, se constató el predominio de pacientes en la categoría cuidados mínimos, $73 \%$ y $46 \%$ respectivamente. En la clínica médica, la mayoría de los pacientes, permanecieron en la misma categoría de cuidado identificada durante su admisión, mientras que en la quirúrgica, hubo una variación entre las categorías de cuidado, sobre todo en el periodo postoperatorio. Los indicadores cuidado corporal, locomoción e integridad cutánea/mucosa fueron los más se encontraron en la transición de categoría de cuidado. Los hallazgos de este estudio permiten ayudar en la toma de decisiones gerenciales referentes a la optimización de recursos humanos y al costo de la asistencia de enfermería.

DESCRIPTORES: evaluación en enfermería; carga de trabajo; pacientes internos/clasificación

\section{VARIABILIDADE DO GRAU DE COMPLEXIDADE ASSISTENCIAL DO PACIENTE EM RELAÇÃO À EQUIPE DE ENFERMAGEM}

Esta pesquisa exploratória-descritiva teve por finalidade investigar a variabilidade da complexidade assistencial do paciente em relação à equipe de enfermagem, durante a internação, e identificar os indicadores de cuidados que mais contribuem para a transição entre as categorias, e foi realizada em unidades de internação clínica e cirúrgica de um hospital escola no interior do Estado de São Paulo. Foram classificados 80 pacientes da admissão à alta, utilizando-se o instrumento de classificação proposto e validado por Perroca. Tanto nas unidades de internação de clínica como na cirúrgica, encontrou-se predominância de pacientes na categoria de cuidados mínimos, 73 e 46\%, respectivamente. Os pacientes clínicos, em sua maioria, permaneceram na categoria de cuidado identificada na admissão, enquanto na cirúrgica, houve variação entre as categorias de cuidado, principalmente, no pós-operatório. Os indicadores cuidado corporal, locomoção e integridade cutâneo-mucosa foram os mais envolvidos na transição de categoria de cuidado. Os achados permitem subsidiar decisões gerenciais.

DESCRITORES: avaliação em enfermagem; carga de trabalho; pacientes internados/classificação

${ }^{1}$ Student Nurse at Real Sociedade Beneficente Espanhola, Brazil; ${ }^{2}$ RN, Ph.D. in Nursing, Faculty at Faculdade de Medicina de São José do Rio Preto, Brazil, e-mail:marcia.perroca@famerp.br; ${ }^{3}$ RN, Doctoral student in Nursing, Faculty at Faculdade de Medicina de São José do Rio Preto, Brazil. 


\section{INTRODUCTION}

Nurses' work process, in its double - care and management (organization of the resources necessary for the care process) - dimension can be considered as complex, dynamic and articulated, requiring adequate and rapid decision making. One way to prepare nurses to accomplish this purpose is to apply the Patient Classification System (PCS). This method allows for the determining, validating and monitoring of individualized nursing care to groups of patients with specific needs, assuring greater effectiveness and productivity of nursing personnel ${ }^{(1-2)}$. The system functionality provides information about the patient's nursing care requirements, the time the team spent with direct and indirect care, and the quantitative and qualitative of personnel to meet the patient's biopsychosocial and spiritual needs ${ }^{(3)}$.

The concept of patient classification emerged in the United States in the 1970s, when the different levels of patient care intensity began to be considered within the same hospitalization ${ }^{(4)}$. From then on, PCS has been internationally considered as the nurse management instrument (tool), supporting patient care planning and service organization, as well as providing information to the decision-making process as to staffing projection and allocation, productivity monitoring and health care $\operatorname{costs}^{(1,5)}$.

The identification of nursing care needs permits assessing and adjusting the required workload for the available nursing team ${ }^{(3)}$. Thus, PCS should be used as an instrument to support nurses, justifying additional needs of personnel when both a variation in care needs and, consequently, an increase in work volume at the unit are identified. PCS is also used to guide decisions related to both nursing team recruitment and selection.

The amount and strength of resources needed for care delivery are also established by the patient's care intensity, that is, the greater the nursing care needs, the higher the associated costs will be ${ }^{(6)}$. Thus, PCS can also be used for nursing care costing associated to cost accounting methods $^{(7)}$.
Over the past few years, much has been studied about nursing care intensity as a workloadrelated factor to calculate staffing requirements ${ }^{(8-}$ 10). However, there are no studies, in the literature, about the variations in hospitalized patients' care needs concerning nursing team demands. In the light of this context, the present study aims to:

- investigate the variability of patients' nursing care needs during hospitalization;

- identify the care indicators that most contribute to the transition between care categories.

\section{METHOD}

This descriptive-exploratory research was carried out at clinical and surgical inpatient units of a large teaching hospital located in the interior of São Paulo State, Brazil. The study population included 80- 40 clinical and 40 surgical- patients with length of hospital stay ranging from more than three days to a maximum of 30 days. This criterion was employed to permit studying the variability degree of patient's care intensity during hospitalization. For the characterization of the hospitalized patients according to nursing care needs, a patient classification instrument proposed and validated by Perroca was used ${ }^{(11)}$. This tool is composed of 13 critical indicators covering psychobiological and psychosocial care dimensions. Its application permits classifying the patient into four care categories as follows: minimal, intermediate, semi-intensive and intensive care. The minimum score is 13 and the maximum 65 .

Data were collected from July to September 2006 after approval by the Research Ethics Committee and authorization by the nurse manager of the investigated units. Every day, at a scheduled time, one of the researchers classified the patients, since the moment of their admission at the unit until hospital discharge. A form was designed, including demographic and clinical characteristics, the scores attained on each indicator, the patients' care category, and complementary information collected from the medical charts and together with the nursing team. 
Data gathered from the forms were organized using Microsoft EXCEL spreadsheets and statistically processed using Minitab Statistical Software (MINITAB) v. 12.22. Descriptive data are expressed as frequencies, mean, and standard deviation. In order to study the probabilities of transition between care categories, a Markov chain model was used. This chain describes the status of a system at consecutive intervals. Status alterations are called transitions. A process can be considered a Markov chain when the distribution of the status probabilities in the present depends on the distribution in the immediate past only ${ }^{(12)}$. In order to establish which care indicators interfere in the transitions, the Principal Components Analysis (PCA) through a matrix correlation among indicators and analysis of variance (ANOVA) of the first principal component with Tukey's paired comparisons were used, and $p<.05$. The principal components analysis consists of a transformation technique of variables, and it aims, among others, to create new variables capable of expressing the information enclosed in the original data set (the indicators). Analysis of variance is a procedure used to test the significance of differences between the means of two or more groups ${ }^{(13)}$.

\section{RESULTS}

During the study period, 642 assessments were performed - 313 clinical patients and 329 surgical patients. The majority of the patients classified at the inpatient care units were male. The mean age of clinical and surgical patients was $64 \pm$ 17.3 years (range 17 to 86 years old) and $53 \pm$ 16.4 years (range 18 to 89 years old), respectively. In both inpatient units, patients with a length of hospitalization ranging from six to ten days were predominant (Table 1). The mean duration of hospital stay was $7.8 \pm 2.7$ days for clinical and 8.2 \pm 3.4 days for surgical patients, respectively, ranging from four to 17 days in both units.
Table 1 - Demographic data of patients. São José do Rio Preto, 2006

\begin{tabular}{|c|c|c|}
\hline Demographic data & $\begin{array}{c}\begin{array}{c}\text { Clinical patient } \\
n=40\end{array} \\
\text {. }\end{array}$ & $\begin{array}{c}\begin{array}{c}\text { Surgical patient } \\
n=40\end{array}\end{array}$ \\
\hline \multicolumn{3}{|l|}{ Gender } \\
\hline Female & 13 & 15 \\
\hline Male & 27 & 25 \\
\hline \multicolumn{3}{|l|}{ Age group (years) } \\
\hline$\leq 20$ anos & 1 & 1 \\
\hline 21 a 30 anos & 2 & 3 \\
\hline 31 a 40 anos & 3 & 4 \\
\hline 41 a 50 anos & 3 & 8 \\
\hline 51 a 60 anos & 7 & 8 \\
\hline 61 a 70 anos & 6 & 11 \\
\hline 71 a 80 anos & 15 & 3 \\
\hline$>80$ anos & 5 & 2 \\
\hline \multicolumn{3}{|l|}{ Medical Specialties } \\
\hline Cardiology/ Cardiac Surgery & 7 & 11 \\
\hline General Surgery & - & 11 \\
\hline Internal Medicine & 8 & - \\
\hline Hematology & 4 & - \\
\hline Nephrology & 5 & - \\
\hline Oncology & 4 & - \\
\hline Orthopedics & - & 5 \\
\hline Otolaryngology & 1 & 2 \\
\hline Pneumology & 4 & - \\
\hline Proctology & - & 4 \\
\hline Rheumatology & 3 & - \\
\hline Urology & - & 5 \\
\hline Others * & 4 & 2 \\
\hline \multicolumn{3}{|l|}{ Days of hospitalization } \\
\hline $3-5$ & 10 & 10 \\
\hline $6-10$ & 27 & 20 \\
\hline $11-15$ & 2 & 7 \\
\hline$\geq 16$ & 1 & 3 \\
\hline \multicolumn{3}{|l|}{ Type of discharge } \\
\hline Medical discharge & 37 & 40 \\
\hline Death & 3 & - \\
\hline
\end{tabular}

* Ophthalmology, Geriatrics, Gastroenterology, Plastic Surgery and Vascular Surgery.

Mean frequency was used to estimate the probability of transition between care categories of patients at both units (Table 2). Clinical patients presented a probability rate of approximately $97 \%$ of remaining in the same care category; of these, $73 \%$ remained in a minimum care category. Although the variation in surgical patients' nursing care needs level showed to be significant $(n=31)$, the possibility of patients remaining in the same care category was around $78 \%$. In this group, the highest probability was to remain in the minimum care category $(46 \%)$, followed by the intermediate care category $(30 \%)$. 
Table 2 - Estimate of care category transition probability. São José do Rio Preto, 2006

\begin{tabular}{|c|c|c|c|c|c|c|c|c|c|c|c|c|c|c|c|c|}
\hline \multirow{2}{*}{ Clinic } & \multicolumn{16}{|c|}{ Mean Frequency } \\
\hline & P1-1 & P1-2 & P1-3 & P1-4 & P2-1 & P2-2 & P2-3 & P2-4 & P3-1 & P3-2 & P3-3 & P3-4 & P4-1 & P4-2 & P4-3 & P4-4 \\
\hline Medical & 0,73 & 0,01 & - & - & 0,02 & 0,14 & - & - & - & - & 0,08 & - & - & - & - & 0,02 \\
\hline Surgical & 0,46 & 0,10 & 0,01 & - & 0,10 & 0,30 & 0,01 & - & - & 0,01 & 0,02 & - & - & - & - & - \\
\hline
\end{tabular}

1. Minimum care; 2 - Intermediate care; 3 - Semi-intensive care; 4 - Intensive care

P1-1 - Probability of minimum care patients remaining in the category; P1-2 - Probability of minimum care patients' shift to intermediate care category, and so on

To verify the association of the 13 care indicators and their effects on patients' classification, principal components analysis was performed. This analysis indicated the most significant factors in determining differences among the patients, organizing them by their capacity to explain overall variation and measurement of dispersion. Table 3 shows the principal components analysis of the most significant factors, indicating to what extent each factor explains the variability and to what extent each variable enters in the composition of the factors by factorial weight. Variables 1,10 , and 12, regarding Mental State and level of consciousness, Health education and Communication indicators, were excluded because their capacity of explaining the variability of care categories was very low.

Table 3 - Presentation of the factorial weight of the Principal Components Analysis. São José do Rio Preto, 2006

\begin{tabular}{ccccc}
\hline \multicolumn{5}{c}{ Covariance Matrix } \\
\hline Eigenvalue & 5,475 & 1,047 & 1,005 & 0,820 \\
Rate & 0,548 & 0,105 & 0,100 & 0,082 \\
Cumulative & 0,548 & 0,652 & 0,753 & 0,835 \\
Eigenvalue & 0,291 & 0,173 & 0,107 & 0,030 \\
Rate & 0,029 & 0,017 & 0,011 & 0,003 \\
Cumulative & 0,969 & 0,986 & 0,997 & 1,000 \\
\hline Variables & $\mathbf{P C ~ 1}$ & $\mathbf{P C ~ 2}$ & $\mathbf{P C ~ 3}$ & $\mathbf{P C ~ 4}$ \\
\hline Ind 2 & 0,212 & $-0,356$ & 0,480 & 0,484 \\
Ind 3 & 0,334 & 0,020 & 0,269 & 0,255 \\
Ind 4 & 0,138 & 0,720 & $-0,307$ & 0,536 \\
Ind 5 & 0,350 & $-0,036$ & $-0,019$ & $-0,341$ \\
Ind 6 & 0,398 & $-0,048$ & $-0,154$ & $-0,222$ \\
Ind 7 & 0,399 & $-0,046$ & $-0,160$ & $-0,175$ \\
Ind 8 & 0,366 & $-0,010$ & $-0,209$ & 0,035 \\
Ind 9 & 0,294 & $-0,084$ & 0,219 & 0,233 \\
Ind 11 & 0,092 & 0,584 & 0,659 & $-0,396$ \\
Ind 13 & 0,394 & $-0,015$ & $-0,167$ & $-0,073$ \\
\hline
\end{tabular}

It was observed that the first two factors can explain $65 \%$ of the overall data variation. The first factor was the most important, representing $54.8 \%$ of overall variability, with the greatest discrimination power among patients. In the present research, only factor 1 was considered because the remaining factors' explanatory power was too reduced in comparison with the first factor.

The observation of the factorial weight permitted to identify the care indicators that better explained factor 1 . Thus, the indicators most involved in the transition between categories, mainly in surgical patients, were as follows: 7 (personal hygiene), 6 (locomotion), 13 (skin integrity), 8 (elimination), 5 (motility), 3 (vital signs), 9 (therapy), 4 (nutrition and hydration), and 2 (breathing).

To test the significance of differences among variation means and to verify the accuracy of the outcomes regarding patients' nursing care needs in the four care categories (minimum, intermediate, semi-intensive, and intensive) and the 16 possibilities of transitions (status shifts) between these categories, ANOVA statistical analysis was performed. Actual transitions that occurred and were most frequent among the clients in this study were considered as: 1-2 (minimum-intermediate), 2-1 (intermediate-minimum), and 3-2 (semi-intensiveintermediate), ruling out the possibility of remaining in category 1-1 (minimum-minimum).

$P$ value $<0.0005$ indicates the existence of differences among means and Tukey's multiple paired comparisons showed that the real means of factor 1 follows the sequence: (minimumintermediate) $>$ (intermediate-minimum) and (semiintensive-intermediate). There are no evidences of differences between the last two. 


\section{DISCUSSION}

The daily patient's classification at the investigated inpatient units revealed that the clinical patients presented a trend to remain, during the hospitalization period, in the care category identified upon admission $(n=35)$; the majority of the patients $(n=28)$ remained into the minimum care category.

At the surgical units, however, variation between care categories predominated $(n=31)$; of these, 17 patients shifted from the minimum level to the intermediate level, returning to the minimum classification afterwards. The transitions among care categories occurred at the moment of the surgical procedure and in the immediate post-operative period. Nevertheless, soon afterwards, the patients returned to the baseline care category. It is worth mentioning that, in both units, there have been patients who presented, at some point in time, the semi-intensive care classification, and even one case of intensive care classification at the clinical unit.

Another study carried out at a geriatrics unit, using the same classification instrument, verified that $79.4 \%$ of the patients remained in the same care category after admission; of these, $53.4 \%$ required minimum care ${ }^{(14)}$. Despite the difference in population characteristics, results this study also presented similar to those obtained in the present research.

During the hospitalization period, the patient can remain in the same care category in which he/ she was admitted, increase or decrease his/her nursing care requirements. Considering the four care categories (minimum, intermediate, semi-intensive, and intensive), there are 16 possibilities of transition (status shifts). These transitions do not have to occur orderly, that is, it is not necessary for patients to shift from the current category to another one immediately above or below.

The possibility of remaining in the same care category decreases as the patient's level of nursing care needs increases $(14 \%, 8 \%$, and $2 \%$, respectively, regarding intermediate, semi-intensive and intensive care). Variations in nursing care intensity levels occurred more frequently downwards, starting from a higher towards a lower intensity level, from an intermediate care category to a minimum care category (0.02), than upwards from minimum care to intermediate care level (0.01).

These outcomes highlighted, contrary to all expectations, that clinical patients presented more stable nursing care needs than surgical patients. The lack of literature concerning the theme impairs comparisons of these findings with other studies of care facilities.

The Personal hygiene care indicator was identified in other studies ${ }^{(11,15)}$ as the most significant indicator in establishing nursing care needs. The findings of the present research have also demonstrated that this indicator was the factor that most contributed to the patient's care category shift.

The complexity relates the level of patient's needs, using the volume and intensity of resource consumption during care delivery. Thus, the followup of care complexity during the hospitalization period permits identifying the activities and procedures performed and the time spent by the nursing staff, contributing to a more rational care planning.

The care profile variation guides the calculation of staffing requirements in both qualitative and quantitative terms ${ }^{(3)}$, cost calculation ${ }^{(7,16)}$, planning of nursing budget $^{(7)}$, and impact on the revenue, as payments are made according to resources consumption and time ${ }^{(6)}$.

The traditional accounting methods are restricted to the patient-day cost, not including the variability of nursing care. However, an innovative method based on cost accounting has associated the use of PCS with the relative value unit (RVU) to improve data accuracy. Thus, the patient's care complexity is identified taking into consideration the average duration of the planned care, for the sake of greater adequacy of the time spent on each patient and its real $\operatorname{cost}^{(7)}$.

A limitation of this study was the number of patients assessed at each inpatient unit, despite concerns to consider diversified medical specialties. Thus, further research in other contexts is recommended with a view to a more in-depth discussion, as administering patient care complexity represents a challenge for hospital management. 


\section{CONCLUSION}

The present study allows for conclusions about the variability of patient's care needs and which care areas most contribute to this variability. It was observed that clinical patients presented more stable nursing care needs during the hospitalization period than surgical patients. Personal hygiene, locomotion, and skin integrity were the care indicators most involved in care category transitions.

Nursing staff within the same unit attends to a range of customers in terms of care complexity.
Nurses should get knowledge about how to manage the patient's nursing care requirements in the face of the multiple implications for his/her field of expertise.

\section{ACKNOWLEDGEMENTS}

To Dr. José Antônio Cordeiro for his contributions to the statistical analysis; to the nursing teams at the Hospitalization Units were the study was developed for their constant help with data collection; to César Roberto dos Santos Souza for his cooperation in translating articles

\section{REFERENCES}

1. De Groot HA. Patient classification system evaluation: part two, system selection and implementation. J Nurs Manage $1989 ; 19(7): 24-30$.

2. Willian GH, Anderson J]. Developing a labor and delivery patient classification system. Nurs Manag 1992; 23(10):74-80.

3. Gaidzinski RR. Dimensionamento de pessoal de enfermagem em instituições hospitalares. [tese]. São Paulo (SP): Escola de Enfermagem/USP; 1998.

4. Perroca MG, Gaidzinski RR. Sistema de classificarão de pacientes: construção e validação de um instrumento. Rev Esc Enferm USP 1998; 32(2):153-68.

5. Malloch K, Conovaloff A. Patient classification system. Part 1. The third generation. J Nurs Admin 29(7/8):49-56. 6. Jacques JE. Gestão hospitalar; os custos médicoassistenciais. São Leopoldo: Unisinos; 2006.

7. Falk JA. Gestão de custos para hospitais: conceitos, metodologias e aplicações. São Paulo: Atlas; 2001.

8. Fugulin FMT, Gaidzinski RR, Kurcgant P. Sistema de classificação de pacientes: identificação do perfil assistencial dos pacientes das unidades de internação do HU-USP. Rev Latino-am Enfermagem 2005; 13(1):72-8.

9. Laus AM, Anselmi ML. Caracterização dos pacientes internados nas unidades médicas e cirúrgicas do HCFMRPUSP, segundo grau de dependência em relação ao cuidado de enfermagem. Rev Latino-am Enfermagem 2004; 12(4):643-9.
10. Nicola AL. Dimensionamento de pessoal de enfermagem no hospital universitário do oeste do Paraná. [tese]. Ribeirão Preto (SP): Escola de Enfermagem/USP; 2004.

11. Perroca MG. Instrumento de classificação de pacientes de Perroca: validação clínica. [tese]. São Paulo (SP): Escola de Enfermagem/USP; 2000.

12. Grimmeth G, Stizaker D. Probability and Random Process. Oxford: Claredon Press; 1990.

13. Polit DF, Hungler BP. Fundamentos de pesquisa em enfermagem; 3ed. Porto Alegre (RS): Artes Médicas; 1995. 14. Cordella PB, Polizelli P, Perroca MG. Utilização de instrumento de classificação de pacientes no gerenciamento de uma unidade geriátrica. [CD ROM] . In: $53^{\circ}$ Congresso Brasileiro de Enfermagem; 9-14 outubro 2001. Curitiba (PR): ABEn-PR; 2001.

15. Pavani LMD. Análise do dimensionamento de pessoal de enfermagem na unidade de pós-operatório de cirurgia cardíaca em um hospital universitário especializado em cardiologia. São Paulo. [tese]. São Paulo (SP): Escola de Enfermagem/ USP; 2000.

16. Pimentel ER. Metodologia de custeio baseado em atividades: uma aplicação dos custos indiretos no centro cardiológico de um hospital. [dissertação]. São Paulo (SP): Pontifícia Universidade de São Paulo; 2004.

17. Anselmi ML. Quadro de referência para elaboração do orçamento de enfermagem em instituições hospitalares. [livre docência]. Ribeirão Preto (SP): Escola de Enfermagem da Universidade de São Paulo; 2000. 